\title{
Cloning and Sequencing of the Pancreatic Islet Neogenesis Associated Protein (INGAP) Gene and Its Expression in Islet Neogenesis in Hamsters
}

\author{
Ronit Rafaeloff, ${ }^{\star}$ Gary L. Pittenger, ${ }^{\star}$ Scott W. Barlow, ${ }^{\star}$ Xiao F. Qin, ${ }^{\star}$ Bing Yan, ${ }^{\star}$ Lawrence Rosenberg, ${ }^{\ddagger}$ William P. Duguid, ${ }^{\ddagger}$ \\ and Aaron I. Vinik* \\ The Diabetes Institutes, *Department of Internal Medicine, Eastern Virginia Medical School, Norfolk, Virginia 23510; and the \\ ${ }^{\ddagger}$ Department of Surgery, McGill University, Montreal, Quebec, H3G 1A4, Canada
}

\begin{abstract}
Induction of islet neogenesis by cellophane wrapping $(\mathrm{CW})$ reverses streptozotocin-induced (STZ) diabetes. Administration of Ilotropin, a protein extract isolated from $\mathrm{CW}$ pancreata, causes recapitulation of normal islet ontogeny and reverses STZ diabetes, reducing mortality by $50 \%$. We investigated the hypothesis that a novel gene encoding a constituent of Ilotropin was expressed in the hamster pancreas undergoing islet neogenesis. Islet neogenesis associated protein (INGAP) is a product of a novel gene expressed in regenerating hamster pancreas. Northern blot analysis showed a strong single transcript of $850 \mathrm{bp}$ at 1 and $2 \mathrm{~d}$ after $\mathrm{CW}$ that disappeared by the 6th day and was absent from untreated control pancreata. INGAP gene is expressed in acinar cells, but not in islets. Western blot analysis demonstrated the presence of INGAP in Ilotropin but not in extracts from control pancreata. A synthetic pentadecapeptide, corresponding to a region unique to INGAP, stimulated a 2.4-fold increase in $\left[{ }^{3} \mathrm{H}\right]$ thymidine incorporation into hamster duct epithelium in primary culture and a rat pancreatic duct cell line but had no effect on a hamster insulinoma tumor cell line. A portion of human INGAP gene was cloned and appears to be highly homologous to the hamster gene. This data suggests that the INGAP gene is a novel pancreatic gene expressed during islet neogenesis whose protein product is a constituent of Ilotropin and is capable of initiating duct cell proliferation, a prerequisite for islet neogenesis. (J. Clin. Invest. 1997. 99:2100-2109.) Key words: islet neogenesis • INGAP gene $\cdot$ hamster
\end{abstract}

\section{Introduction}

Neogenic pancreatic islet cells differentiate from a protodifferentiated islet cell precursor in the duct epithelium or the mesenchyme adjacent to the ducts (1-5). Several model systems

The nucleotide sequence data reported in this paper has been submitted to the EMBL/GenBank Data Libraries under accession number (HS4629-U41737, INGAP-U41738).

Address correspondence to Dr. Aaron I. Vinik, the Diabetes Institutes, 855 W. Brambleton Ave., Norfolk, VA 23510. Phone: 757446-5912; FAX: 757-446-5868; E-mail: aiv@di1.evms.edu

Received for publication 24 May 1996 and accepted in revised form 13 February 1997.

J. Clin. Invest.

(C) The American Society for Clinical Investigation, Inc.

0021-9738/97/05/2100/10 \$2.00

Volume 99, Number 9, May 1997, 2100-2109 have been developed to study mesenchymal factors that might be involved in new islet formation (4-8). Cellophane wrapping $(\mathrm{CW})^{1}$ of the adult hamster pancreas leads to the induction of new islet formation from ducts within 2 wk with recapitulation of normal fetal ontogeny $(2,9)$, in the absence of an inflammatory response (1). Glucagon, somatostatin, and insulin appear sequentially to form a mature islet $(1,2)$. CW is capable of reversing streptozotocin (STZ)-induced diabetes in $>50 \%$ of cases (10). We demonstrated, using parabiosis, that the effect was not hormonal and that there was a paracrine or autocrine mechanism regulating islet neogenesis (1). We hypothesized that a unique locally produced factor(s) was responsible for islet cell regeneration. A partially purified preparation of $\mathrm{CW}$ pancreata, called Ilotropin, was shown to induce new islet formation from duct epithelium and sequential appearance of glucagon, somatostatin, and insulin, and thereby reverse STZinduced diabetes by inducing pancreatic islet neogenesis (11). Ilotropin has only been partially characterized as a protein(s) that is acid and heat stable, ethanol-precipitable, trypsin-sensitive, with an apparent molecular weight in the range of 29-44 $\mathrm{kD}$, and is not sialated (1). The gene(s) encoding proteins in Ilotropin have not been identified.

Our approach for identifying and characterizing the genes responsible for regeneration has been to compare genes expressed in CW versus control pancreata. Methods used previously only permitted screening of known molecules on an individual basis (12). Differential mRNA display technique has been recently described and used to identify differences in subsets of mRNA samples (13). We previously reported on using the mRNA differential display technique and the identification of several clones expressed in regenerating, but not in control pancreata (14). We report here the isolation, sequence, and localization of a novel gene whose protein product is a constituent of Ilotropin, and demonstrate the ability of a unique synthetic peptide corresponding to a region of islet neogenesis associated protein (INGAP) to stimulate proliferation of pancreatic ductal cells in vitro.

\section{Methods}

Animals and induction of islet neogenesis. 120 outbred female Syrian golden hamsters, 7 wk of age (Charles River, WV), were used. All experiments were conducted in accordance with the principles and procedures outlined in the NIH Guide for the Care and Use of Laboratory Animals. Our model for surgical induction of cell proliferation in the pancreas of the Syrian golden hamster has been described previ-

1. Abbreviations used in this paper: $\mathrm{CW}$, cellophane wrapping; HIT, hamster insulinoma tumor; INGAP, islet neogenesis associated protein; PAP, pancreatitis associated protein; PSP, pancreatic stone protein; STZ, streptozotocin. 
ously (1-3). Briefly, a midline laparotomy incision is made. With the aid of a stereo dissecting microscope, the distal common bile duct and head of the pancreas are exposed. Using blunt dissection, an avascular plane is developed to allow the placement of a $2 \mathrm{~mm}$-wide strip of sterile cellophane tape (Imperial Tobacco, Montreal, Canada), which is wrapped around the head of the gland and tied loosely in position.

Ilotropin administration and immunocytochemistry. 10 female Syrian golden hamsters were allocated to receive $500 \mu \mathrm{l}$ of Ilotropin, twice daily for $7 \mathrm{wk}$. A control group received $500 \mu \mathrm{l} 0.9 \% \mathrm{NaCl}$ (saline) twice daily for $7 \mathrm{wk}$. We chose not to use cytosol extract from nonwrapped hamster pancreata for the control group in these studies because we have previously demonstrated that its activity was no different from saline (15). Ilotropin was prepared as described previously $(1,11)$. Briefly, after pentobarbital anesthesia, cellophane wrapping of the pancreas was performed on female 6-8 wk old Syrian golden hamsters. $10 \mathrm{~d}$ later, the pancreas was collected and homogenized in Tris buffer containing $1 \mu \mathrm{g} / \mathrm{ml}$ leupeptin, $40 \mu \mathrm{g} / \mathrm{ml}$ soybean trypsin inhibitor, and $1 \mathrm{mM}$ phenyl-methyl-sulfonyl fluoride. The homogenate was centrifuged at $100,000 \mathrm{~g}$ for $30 \mathrm{~min}$ and the supernatant was collected. The solution was heated to $65^{\circ} \mathrm{C}$ for $30 \mathrm{~min}$ and centrifuged at $19,000 \mathrm{~g}$. The supernatant was collected and diluted 1:40 with $10 \%$ perchloric acid. The solution was centrifuged at 19,000 $\mathrm{g}$ and the supernatant collected. After $\mathrm{pH}$ neutralization, the material was brought to $70 \%$ ethanol by the addition of $100 \%$ ethanol, and centrifuged at $19,000 \mathrm{~g}$. The pellet was collected and resuspended in normal saline for subsequent study. For immunocytochemistry, pancreas was removed and fixed in $10 \%$ buffered formalin. The specimens were embedded in paraffin and $5 \mu \mathrm{m}$ sections were cut. Immunoperoxidase staining for insulin and glucagon was performed on deparaffinized sections using Dako Kits (Dako Corp., Carpenteria, CA). The primary antibodies were raised in rabbits and the secondary antibody was swine anti-rabbit immunoglobulin. Nonspecific staining was excluded by using the secondary antibody without the primary antibody, and specificity was determined by neutralization with excess antigen. To visualize the immunoreactivity, slides were incubated with AEC (3-amino-9-ethylcarbazole) chromagen. Sections were counterstained with hematoxylin and mounted. Photographs were taken under bright field optics.

Cell cultures. Pancreatic duct epithelial cell cultures were prepared from 12 6-8 wk old Syrian golden hamsters. After the induction of pentobarbital anesthesia, the bile duct was exposed and ligated flush with the duodenum. The bile duct was cannulated and the pancreas perfused with a collagenase-chymotrypsinogen solution until the gland was grossly distended. The pancreas was excised and incubated at $37^{\circ} \mathrm{C}$ for $40 \mathrm{~min}$. The enzymatic reaction was stopped by the addition of cold HBSS and the tissue dispersed by vortex. After six washes in cold HBSS, the tissue was filtered through a $94 \mu \mathrm{m}$ steel mesh and the trapped pancreatic duct fragments rinsed off and plated into a solid matrix of collagen gel. The cultures were fed with serumfree medium. After $3 \mathrm{~d}$ in culture, the collagenase had been digested and the small, ductular cysts were plated into a fresh collagen matrix. Cells were used for $\left[{ }^{3} \mathrm{H}\right] \mathrm{TdR}$ incorporation experiments after three such passages.

The cell lines used in this study included ARIP (American Type Culture Collection [ATCC], Rockville, MD), which originates from rat duct epithelium derived from an exocrine pancreatic transplantable tumor, and hamster insulinoma tumor (HIT)-T15 (ATCC), which originates from a hamster pancreatic $\beta$ cell insulinoma.

$m R N A$ differential display and cloning of INGAP $c D N A$. Total RNA was extracted from 10 control and $10 \mathrm{CW}$ hamster pancreata and mRNA differential display technique was performed as previously described (14). Briefly, cDNA was synthesized from $0.2 \mu \mathrm{g}$ of total RNA using $1 \mu \mathrm{M}$ of the four $3^{\prime} \mathrm{T} 12 \mathrm{VN}$ primers (where $\mathrm{V}$ is the degenerate position containing $\mathrm{A}, \mathrm{C}$ or $\mathrm{G}$, and $\mathrm{N}$ is any one of the four deoxynucleotides), $1 \times$ reverse transcription buffer, $25 \mu \mathrm{M}$ each dGTP, dATP, dCTP, dTTP and $100 \mathrm{U}$ of moloney murine leukemia virus reverse transcriptase. The resulting cDNA was amplified using PCR with 10mer arbitrary primers (GenHunter Corp., Brookline,
MA), $1 \times$ PCR buffer, $1 \mu \mathrm{M}$ of the respective T12VN, $2 \mu \mathrm{M}$ dNTPs, $2 \mathrm{U}$ of AmpliTaq DNA polymerase (Boehringer Mannheim Biochemicals, Indianapolis, IN) and $10 \mu \mathrm{Ci}\left[{ }^{35} \mathrm{~S}\right] \mathrm{dATP}(1,300 \mathrm{Ci} / \mathrm{mmol}$, Dupont-New England Nuclear, Boston, MA). The amplified cDNAs were separated on a $6 \%$ DNA sequencing gel and bands unique to $\mathrm{CW}$ were recovered and reamplified by PCR using appropriate primers. The PCR products were visualized on a $5 \%$ acrylamide gel to verify size, eluted and cloned into the pCR-II vector using TA cloning system from Invitrogen Corp. (San Diego, CA). DNA sequencing was performed with either T7 or SP6 primer using the TaqTrack sequencing system from Promega Corp. (Madison, WI) and sequences were compared with the GenBank data base (PC/Gene by IntelliGenetics Inc./Betagen, Mountain View, CA) for similarity to known sequences. A cDNA library was constructed from mRNA isolated from $\mathrm{CW}$ pancreas using Oligo $\mathrm{d}(\mathrm{T})$ primed synthesis, and ligation into pcDNA3 (Invitrogen Corp.). The number of primary recombinants in the library was $1.2 \times 10^{6}$ with an average size of $1.1 \mathrm{~kb}$. The cDNA library was screened for clones of interest using high density colony plating techniques. Colonies were lifted onto nylon membranes (Schleicher \& Schuell, Keene, NH) and further digested with proteinase $\mathrm{K}(50 \mu \mathrm{g} / \mathrm{ml})$. Treated membranes were baked at $80^{\circ} \mathrm{C}$ for $1 \mathrm{~h}$ and hybridized at $50^{\circ} \mathrm{C}$ for $16-18 \mathrm{~h}$ with $1-5 \times 10^{6} \mathrm{cpm} / \mathrm{ml}$ of $\left[\alpha^{32} \mathrm{P}\right] \mathrm{dCTP}$ (DuPont-New England Nuclear, Boston, MA) radiolabeled RD19-2 probe. Colonies with positive hybridization signal were isolated, compared to Northern mRNA transcript size, and sequenced to confirm identity with the RD19-2 sequence.

Northern blot analysis. Total RNA $(30 \mu \mathrm{g})$ was separated on a denaturing gel, transferred to nylon membrane, hybridized, and washed as previously described (14). cDNA probes used in Northern hybridization were labeled through the incorporation of $\left[\alpha^{32} \mathrm{P}\right] \mathrm{dCTP}$ using random primed synthesis to a specific activity of $>10^{9} \mathrm{cpm} / \mu \mathrm{g}$. A 350 bp RD19-2 cDNA probe was generated by PCR from hamster pancreatic total RNA, a 766 bp INGAP cDNA was cloned in our lab and a $1,000 \mathrm{bp}$ amylase cDNA probe was generously donated by Chris Newgard (University of Texas, Dallas, TX). A $\left[\gamma^{32} \mathrm{P}\right]$-ATP (DuPontNew England Nuclear) 5' end-labeled 24 mer synthetic oligonucleotide for the $18 \mathrm{~S}$ ribosomal mRNA was used as a loading control. Autoradiography was performed at $-80^{\circ} \mathrm{C}$ for $1 \mathrm{~h}$ to $5 \mathrm{~d}$ by exposing gels to scientific imaging film (X-OMAT/AR; Eastman Kodak, Rochester, NY).

In situ hybridization. We used RNA probes instead of cDNA to form stronger hybrids with the mRNA, thus allowing high stringency hybridization and washes. Synthesis of RNA probe was performed as previously described (12). In situ hybridization was performed according to the protocol of Bondy (16) with some modifications. Control and CW pancreata were dissected out and snap frozen in TissueTek (Miles Inc., Elkhart, IN) and liquid $\mathrm{N}_{2}$. Frozen sections (8-10 $\mu \mathrm{m})$ were cut on a cryostat at $-20^{\circ} \mathrm{C}$. For prehybridization sections were warmed to $25^{\circ} \mathrm{C}$, fixed in $4 \%$ formaldehyde, rinsed in phosphate buffered saline, and soaked for $10 \mathrm{~min}$ in $0.25 \%$ acetic anhydride, 100 $\mathrm{mmol} /$ liter triethanolamine, $\mathrm{pH} 8.0$, to block positive charges. Tissue was then dehydrated, delipidated in chloroform, rehydrated, and air dried. ${ }^{35} \mathrm{~S}$-labeled probes were added to hybridization buffer composed of $50 \%$ formamide, $0.2 \mathrm{M} \mathrm{NaCl}, 50 \mathrm{mM}$ Tris- $\mathrm{HCl}, 2.5 \mathrm{mM}$ EDTA, $10 \%$ dextran sulfate, $250 \mu \mathrm{g} / \mathrm{ml} t$ RNA, $10 \mathrm{mM}$ DTT and $1 \times$ Denhardt's. $5 \times 10^{7} \mathrm{cpm}$ of probe in $70 \mu \mathrm{l}$ of hybridization buffer was applied to the slides, to which coverslips were added and placed in humidified chambers for $18 \mathrm{~h}$ at $55^{\circ} \mathrm{C}$. Posthybridization included washing the slides several times in $4 \times$ SSC to remove the cover slips and hybridization buffer. Sections were then dehydrated and immersed in $50 \%$ formamide, $300 \mathrm{mmol} /$ liter $\mathrm{NaCl}, 20 \mathrm{mmol} /$ liter Tris$\mathrm{HCl}, 1 \mathrm{mmol} /$ liter EDTA, $10 \mathrm{mmol} / /$ liter DTT at $60^{\circ} \mathrm{C}$ for $10 \mathrm{~min}$. Sections were then treated with RNase A $(20 \mu \mathrm{g} / \mathrm{ml})$ for $30 \mathrm{~min}$ at $37^{\circ} \mathrm{C}$ followed by three washes in $0.5 \mathrm{M} \mathrm{NaCl}, 10 \mathrm{mM}$ Tris, $1 \mathrm{mM}$ EDTA, pH 8.0 (NTE), and a 15 min wash in $0.1 \times \mathrm{SSC}$ at $50^{\circ} \mathrm{C}$. Slides were air dried and exposed to Hyperfilm-beta Max (Amersham Corp., Arlington Heights, IL) for $4 \mathrm{~d}$, then dipped in Kodak NTB2 emulsion, dried, and stored at $4^{\circ} \mathrm{C}$. Following $10 \mathrm{~d}$ of exposure, the slides were developed with Kodak D-19 developer and stained with hematoxylin 

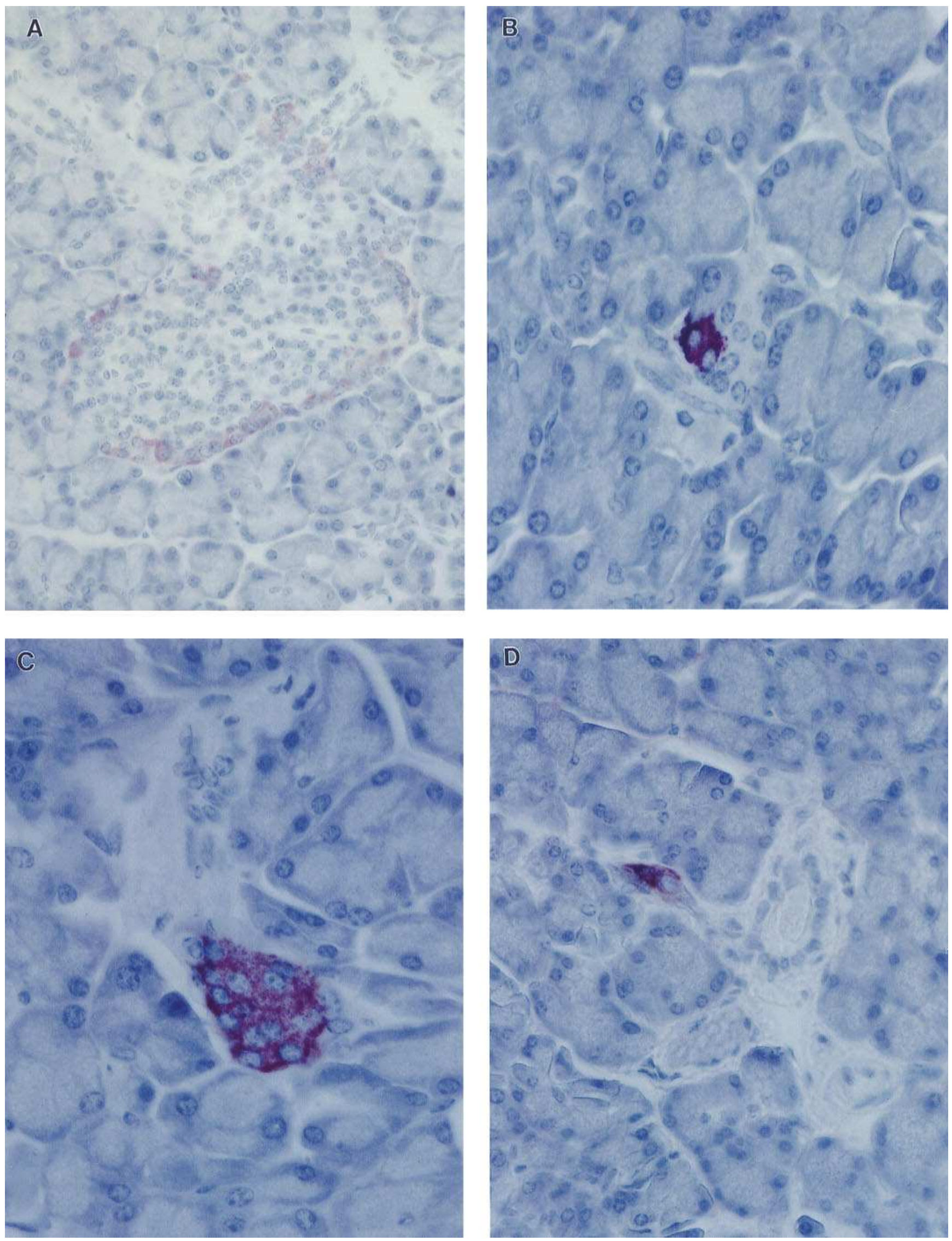

Figure 1. Effect of Ilotropin administration on islet neogenesis. (A) Hamster pancreas $3 \mathrm{wk}$ after initiation of Ilotropin administration. A normal islet is shown adjacent to an intralobular duct. Cells are stained with antibody to glucagon. Note the normal distribution of $\alpha$ cells in the periphery of the islet and the glucagon-positive cells arising from the duct. (B) Hamster pancreas $3 \mathrm{wk}$ after initiation of Ilotropin administration.

Shown are glucagon-positive cells budding from the adjacent intralobular duct. (C) Hamster pancreas 3 wk after initiation of Ilotropin administration. Shown is a focus of insulin-positive cells. $(D)$ Hamster pancreas $2 \mathrm{wk}$ after the initiation of Ilotropin administration. Intralobular duct with one cell staining positive for glucagon. 
and eosin. Photographs were taken under dark-field and bright-field optics.

$\left[{ }^{3} H\right] T d R$ incorporation. A pentadecapeptide corresponding to amino-acids $104-118$ of INGAP was synthesized by Genosys Biotechnologies (The Woodlands, TX). The proliferative response of pancreatic duct, ARIP and HIT-T15 cells to INGAP peptide was quantified by $\left[{ }^{3} \mathrm{H}\right] \mathrm{TdR}$ incorporation. Duct cells, HIT-T15 and ARIP cells were plated onto 6-well plates and cultured in Ham's F-12K media containing $10 \%$ FBS for $24-48 \mathrm{~h}$ or until reaching $50-60 \%$ confluency. Then the media was removed and the cells were incubated for $24 \mathrm{~h}$ either with varying concentrations of INGAP peptide $(100-1500 \mathrm{ng} / \mathrm{ml})$ or an equal volume of control diluent in the presence of $10 \mu \mathrm{Ci}$ of $\left[{ }^{3} \mathrm{H}\right] \mathrm{TdR}(80.4 \mathrm{Ci} / \mathrm{mmol}$, DuPont-New England Nuclear). As a negative control we used $60-500 \mathrm{ng} / \mathrm{ml}$ nerve growth factor (NGF) protein in the incubation instead of INGAP. DNA was precipitated with $15 \%$ TCA and extracted with $2 \mathrm{~N} \mathrm{NaOH}$ and the recovered radioactivity measured. Data were recorded as recovered $\mathrm{cpm} / \mu \mathrm{g}$ DNA and analyzed using ANOVA and post hoc Dunnett's test. Significance was accepted at the $5 \%$ level.

Recombinant protein expression in a prokaryotic system. We generated a new INGAP cDNA by PCR which excluded the $5^{\prime}$ UTR region (nucleotides 1-35, see Fig. $3 A$ ) and the signal peptide (nucleotides 36-113), had two new restriction enzyme recognition sites enabling the insertion of the new construct into pQE-31 expression vector (QIAGEN, Inc., Chatsworth, CA), and encoded six histidine residues at the $\mathrm{NH}_{2}$-terminus. This expression vector provides a high-level expression in Escherichia coli of proteins containing a histidine affinity tag at the $\mathrm{NH}_{2}$-terminus. The construct was transformed into TOP10F' competent cells (E. coli host strain from Invitrogen Corp.). The positive clones were identified, verified by restriction enzyme digestion and the DNA isolated. The DNA was transformed into a different competent E. coli strain, M15(pREP4) and expression of the protein was induced by isopropyl- $\beta$-D-thiogalactoside (IPTG). The His-tagged protein was isolated by $\mathrm{Ni}^{2+}$ agarose affinity purification (QIAGEN, Inc.) according to the recommended method.

Western blot analysis. INGAP antibody was raised in a rabbit (Genosys Biotechnologies) against a synthetic pentadecapeptide corresponding to amino acids 104-118 of the deduced INGAP protein. For Western blotting, Ilotropin was diluted 1:1 in sample buffer with $1 \%$ SDS and $2 \% \beta$-mercaptoethanol in Tris, $\mathrm{pH}$ 6.8. The proteins were separated by SDS-PAGE on a $12 \%$ gel and transferred to Immobilon-P membranes (Millipore Corp., Bedford, MA) at constant voltage for $18 \mathrm{~h}$. The membrane was blocked with $10 \%$ normal goat serum and $1 \%$ BSA in $50 \mathrm{mM}$ Tris, $\mathrm{pH}$ 7.4. The membrane was exposed for 60 min to anti-INGAP antibody, washed with PBS and exposed for $30 \mathrm{~min}$ to peroxidase-labeled goat anti-rabbit IgG. After washing with PBS, the peroxidase-labeled proteins were revealed with enzyme chemiluminescence (Amersham Corp.). To test for specificity, the membrane was stripped with $200 \mathrm{mM}$ glycine in PBS, $\mathrm{pH} 2.5$, and retested using the primary antibody solution preabsorbed with $1 \mu \mathrm{g} / \mathrm{ml}$ of INGAP peptide added.

\section{Results}

Induction of islet neogenesis by cellophane wrapping. As we have shown previously (1), cellophane wrapping of the hamster pancreas leads to induction of ductal cell proliferation and new islet formation. Using this model we have identified in the CW a local pancreatic factor which we have termed Ilotropin (17) which is capable of reversing diabetes when given intraperitoneally to STZ-treated hamsters (11). Here, we show that in the animals treated with Ilotropin three patterns of islet-cell distribution could be identified: $(a)$ islets in which both insulin and glucagon cell types were present (Fig. $1 A$ ); $(b)$ nests of cells stained exclusively for either insulin or glucagon (Fig. 1, $B$ and $C$ ); and $(c)$ individual cells stained for insulin or glucagon

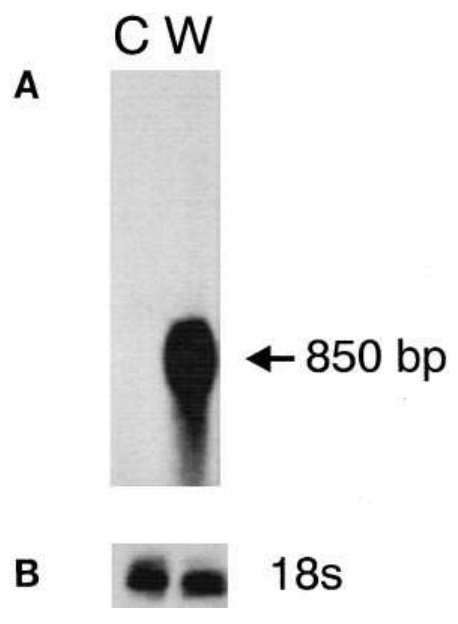

(Fig. $1 D$ ). These were found in duct epithelial cells and in association with cells budding from the ducts. Control agematched animals do not show pattern $b$ or $c$. To determine if unique genes were expressed in regenerating pancreas, we resorted to the mRNA differential display technique.

Identification of RD19-2. Using the mRNA differential display technique, we identified several clones differentially expressed in CW compared with control pancreata (14). One clone, RD19-2, was uniquely expressed in CW as shown by Northern blot analysis (Fig. 2), and we used it to screen a hamster cDNA library prepared from $\mathrm{CW}$ pancreas.

Cloning INGAP cDNA and analysis of the coding region. The nucleotide sequence of the hamster INGAP clone with the longest cDNA insert was determined. As shown in Fig. 3 the hamster cDNA comprises 766 nucleotides (nt), exclusive of the $\operatorname{poly}(\mathrm{A})$ tail and contains a major open reading frame encoding a 175 amino acid protein. The open reading frame is followed by a $3^{\prime}$-untranslated region of $206 \mathrm{nt}$. A typical polyadenylation recognition signal, AATAAA is present $11 \mathrm{nt}$ upstream of the poly(A) tail. Comparison of the nucleotide and deduced amino acid sequence between hamster INGAP and rat pancreatitis associated protein (PAP)-I (18) shows homology in the coding region (60 and 58\% in nucleotide and amino acid sequences, respectively). The predicted amino acid sequence of the hamster INGAP (Fig. 4) also reveals $45 \%$ identity to PAP-II (19), 50\% to PAP-III (20), and 54\% to HIP (21), which is identical to human PAP (22). INGAP also has $40 \%$ identity to the rat Reg protein, which has been found in regenerating islets $(23,24)$. Reg is thought to be identical to the pancreatic stone protein (PSP) (25) and pancreatic thread protein (26). The $\mathrm{NH}_{2}$-terminus of the predicted sequence of INGAP protein contains the initiating methionine codon preceded by a consensus translational start site ACC as defined by Kozak (27), and is highly hydrophobic, which makes it a good candidate for being the signal peptide which would allow the protein to be secreted (28). Similar to PAP/HIP, but different from the Reg/PSP proteins, a potential N-glycosylation site is situated at position 136 of the INGAP sequence. Unique to INGAP is another potential N-glycosylation site situated at position 126. INGAP also shows homology (12/18) (Fig. 4) with a consensus motif in members of the calcium-dependent (C-type) animal lectin as determined by Drickamer (29) including four conserved cysteines which form two disulfide 


\section{A}

gaaaaacacccagatctctgcaagacaggtacc 35

ATG ATG CTT CCC ATG ACC CTC TGT AGG ATG TCT TGG ATG CTG CTT 80 MET MET Leu Pro MET Thr Leu Cys Arg MET Ser TrP MET Leu Leu 15

TCC TGC CTG ATG TTC CTT TCT TGG GTG GAA GGT GAA GAA TCT CAA 125 Ser Cys Leu MET Phe Leu Ser Trp Val Glu GIy Glu GIu Ser Gln 30

AAG AAA CTG CCT TCT TCA CGT ATA ACC TGT CCT CAA GGC TCT GTA 170 lys Lys Leu Pro Ser Ser Arg Ile Thr Cys Pro Gln Gly Ser Val 45

GCC TAT GGG TCC TAT TGC TAT TCA CTG ATT TTG ATA CCA CAG ACC 215 Ala Tyr Gly Ser Tyr Cys Tyr Ser Leu Ile Leu Ile Pro Gln Thr 60

TGG TCT AAT GCA GAA CTA TCC TGC CAG ATG CAT TTC TCA GGA CAC 260 Trp Ser Asn Ala Glu Leu Ser Cys Gln MET His Phe Ser Gly His 75

CTG GCA TTT CTT CTC AGT ACT GGT GAA ATT ACC TTC GTG TCC TCC 305 Leu Ala phe Leu Leu Ser Thr Gly Glu Ile Thr Phe Val Ser Ser 90

CTP GTG AAG AAC AGT TTG ACG GCC TAC CAG TAC ATC TGG ATT GGA 350 Leu Val Lys Asn Ser Leu Thr Ala Tyr Gln Tyr Ile Trp Ile Gly 105

CTC CAT GAT CCC TCA CAT GGT ACA CTA CCC AAC GGA AGT GGA TGG 395 Leu His Asp Pro Ser His GIY Thr Leu Pro Asn Gly Ser Gly trp 120

AAG TGG AGC AGT TCC AAT GTG CTG ACC TTC TAT AAC TGG GAG AGG 440 Lys Trp Ser Ser Ser Asn Val Leu Thr phe Tyr Asn Trp Glu Arg 135

AAC CCC TCT ATT GCT GCT GAC CGT GGT TAT TGT GCA GTT TTG TCT 485 Asn Pro Ser Ile Ala Ala Asp Arg Gly Tyr Cys Ala Val Leu Ser 150

CAG AAA TCA GGT TTT CAG AAG TGG AGA GAT TTTT AAT TGT GAA AAT 530 Gln Lys Ser Gly phe Gln Lys Trp Arg Asp phe Asn Cys Glu Asn 165

GAG CTT CCC TAT ATC TGC AAA TTC AAG GTC tagggcagttctaatttca 579 Glu Leu Pro Tyr Ile Cys Lys Phe Lys Val End

acagcttgaaaatattatgaagctcacatggacaaggaagcaagtatgaggattcactc 638

aggaagagcaagctctgcctacacacccacaccaattccettatatcatctctgctgtt

tttctatcagtatattctgtggtggetgtaacctaaaggctcagagaacaaaataaaa

756

tqtcatcaac

766

\section{B}

INGAP Left primer

1 CAAGACAGGTACCATGATGCTTCCCATGACCCTCTGTAGGATGTCTTGGA

51 TGCTGCTTTCCTGCCTGATGTTCCTTTCTTGGGTGGAAGGTGAAGAATCT

101 CAAAAGAAACTGCCTTCTTCACGTATAACCTGTCCTCAAGGCTCTGTAGC

151 CTATGGGTCCTATTGCTATTCACTGATTTTGATACCACAGACCTGGTCTA

201 ATGCAGAACTATCCTGCCAGATGCATTTCTCAGGACACCTGGCATTTCTT

251 CTCAGTACTGGTGAAATTACCTTCGTGTCCTCCCTTGTGAAGAACAGTTT

301 GACGGCCTACCAGTACATCTGGATTGGACTCCATGATCCCTCACATGGTA

351 CACTACCCAACGGAAGTGGATGGAAGTGGAGCAGTTCCAATGTGCTGACC

401 TTCTATAACTGGGAGAGGAACCCCTCTATTGCTGCTGACCGTGGTTATTG

451 TGCAGTTTTGTCTCAGAAATCAGGTTTTCAGAAGTGGAGAGATTTTAATT

501 GTGAAAATGAGCTTCCCTATATCTGCAAATTCAAGGTCTAGGGCAGTTCT

551 AATTTCAACAGCTTGAAAATATTATGAAGCTCACATGGACAAGGAAGCAA

601 GTATGAGGATTCACTCAGGAAGAGCA

\section{CCTAAGTGAGTCCTTCTCGT}

INGAP Right primer

Figure 3. (A) Nucleotide sequence of hamster INGAP and deduced sequence of encoded immature protein. The noncoding sequence is in lower case letters, and the polyadenylation signal is underlined. $(B)$ Nucleotide sequence of human INGAP. The hamster-specific primers used to generate this fragment from human pancreatic poly $\mathrm{A}^{+}$ RNA are bold and underlined.

bonds. Two extra cysteines found at the amino terminus of INGAP (Fig. 4) are also present in Reg/PSP and PAP/HIP. Computer analysis of the sequence indicates that INGAP protein has a mol wt of 19,940 and an isoelectric point of 7.86. The partial sequence of the human INGAP gene comprises 586 bp that are identical to the hamster gene.

Temporal expression of INGAP $m R N A$. Total RNA extracted from control and $\mathrm{CW}$ pancreas was probed with the hamster INGAP cDNA clone in Northern blot analysis. A strong single transcript of $850 \mathrm{bp}$ was present 1 and $2 \mathrm{~d}$ after $\mathrm{CW}$ which disappeared by the 6th $\mathrm{d}$ and was absent from control pancreas (Fig. 5). The tissue distribution was determined by probing RNA isolated from duodenum, spleen, stomach, lung, liver, heart, and skeletal muscle with INGAP cDNA. Tissues from control animals showed no signal (data not shown). In $\mathrm{CW}$ animals only the duodenum and pancreas expressed a single 850 bp RNA transcript (Fig. 6).

Localization of INGAP $m R N A$ in hamster pancreas. In situ hybridization was performed on specimens from 1,2 , and $10 \mathrm{~d}$ wrapped pancreata and control, nonwrapped pancreata. Tissue sections from 1 and $2 \mathrm{~d}$ wrapped pancreata showed strong hybridization with INGAP mRNA in acinar cells (Fig. 7, $A$ and $B)$, no hybridization, however, was detected in the pancreatic islets. In contrast, in the control animals we observed no expression of INGAP mRNA in pancreatic acinar cells or in the pancreatic islets (Fig. 7, $C$ and $D$ ). The corresponding tissues incubated with a sense probe showed negligible hybridization (data not shown). Sections from $10 \mathrm{~d}$ wrapped pancreata no longer showed hybridization with the INGAP riboprobe (data not shown), which was similar to control pancreata.

Dose response effect of INGAP peptide on $\left[{ }^{3} H\right] T d R$ incorporation into duct epithelial, ARIP and HIT-T15 cells. Because expression of INGAP was a consistent finding early after the $\mathrm{CW}$ and was absent from control pancreata, these data suggest that INGAP might be involved in the initiation of islet neogenesis at an early step in protodifferentiated cell proliferation. To test whether INGAP was capable of initiating cell proliferation from undifferentiated or terminal cells, we synthesized a pentadecapeptide corresponding to amino acids 104-118 of INGAP and examined the biological response. We included this region of the deduced protein because it differs from another related family of genes known to affect islet regeneration, Reg/PSP, in that it has a unique insertion of five amino acids and it precedes a potential $\mathrm{N}$-glycosylation site situated at position 126 , hence, a core of potential biological activity. INGAP was applied to: $(a)$ duct epithelium, which is thought to contain the protodifferentiated stem cells; $(b)$ primitive ARIP cells which are of ductal origin; $(c)$ mature HIT-T15 cells which are of $\beta$ cell origin; and $(d)$ mature normal human islets. Duct epithelial cells treated with INGAP peptide for $24 \mathrm{~h}$ showed a maximal 2.4-fold increase at a dose of $500 \mathrm{ng} / \mathrm{ml}$ of peptide $(1.25 \times$ $10^{4}$ to $3.0 \times 10^{4}\left[{ }^{3} \mathrm{H}\right] \mathrm{TdR} \mathrm{cpm} / \mu \mathrm{g}$ DNA $\left.P<0.05\right)$. ARIP cells similarly treated exhibited a 2.4 -fold increase in $\left[{ }^{3} \mathrm{H}\right] \mathrm{TdR}$ incorporation, $\left(2.3 \times 10^{5}\right.$ to $5.5 \times 10^{5} \mathrm{cpm} / \mu \mathrm{g}$ DNA $\left.P<0.05\right)$ at a dose of $1,000 \mathrm{ng} / \mathrm{ml}$ of INGAP peptide (Fig. 8). In contrast the same amount of INGAP added to the HIT-T15 cell line (Fig. 8) and human islets (data not shown) did not cause any significant effect. To assure that the proliferative response was specific to INGAP peptide, we used an unrelated protein, NGF, which has been suggested by others (30) to be involved in pancreatic islet development. No significant proliferative response was observed with NGF at comparable concentrations (Fig. $9 A$ ). An antibody raised against the synthetic INGAP peptide blocked the proliferative response of duct epithelial cells to INGAP when added to the incubation mixture (not shown). 


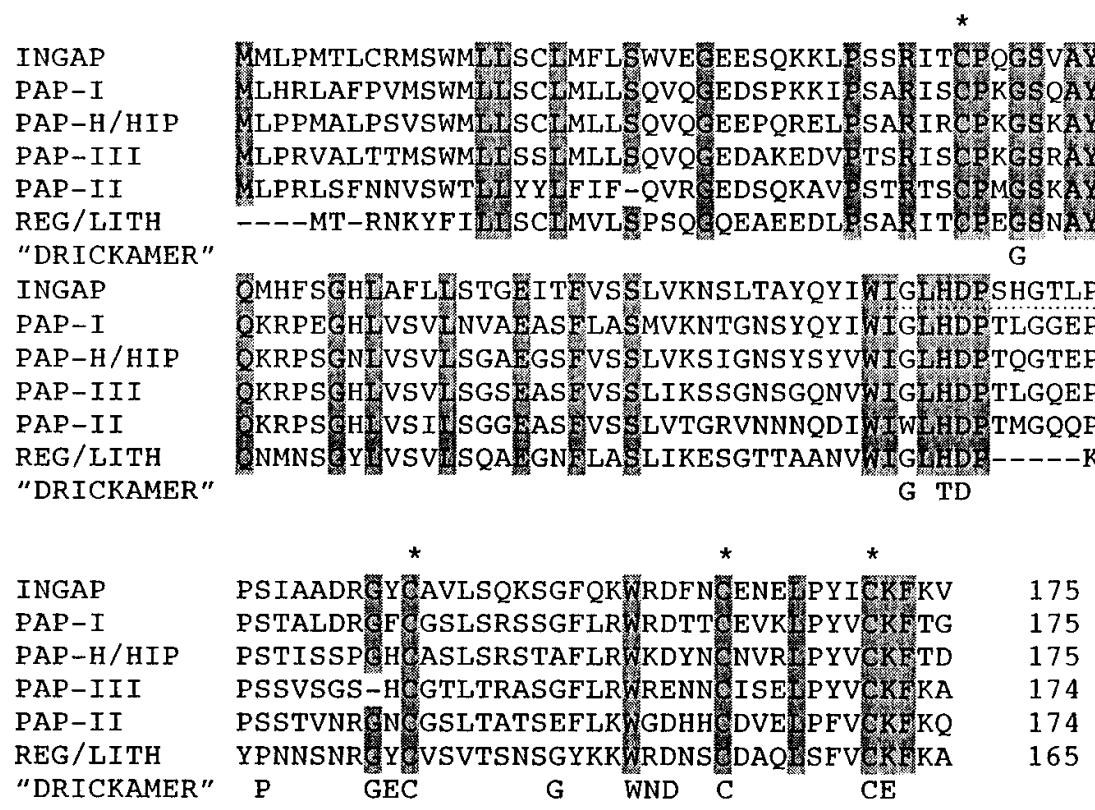

Figure 4. Comparison of amino acid sequences of INGAP, rat PAP-I (PAP-I) (18), human PAP/HIP (PAP-H/HIP) (21, 22), rat PAP-III (PAPIII) (20), rat PAP-II (PAP-II) (19), rat Reg/PSP/Lithostatine (REG/LITH) (23-26) and the invariable motif found by Drickamer in all members of C-type lectins (29). Six conserved cysteines are marked by asterisks, and the putative N-glycosylation sites of INGAP are underlined and bold. The peptide sequence used for the $\left[{ }^{3} \mathrm{H}\right] \mathrm{TdR}$ studies is dotted. Conserved amino acids are shaded.

In order to test whether the full length INGAP protein has biological activity comparable to that of the synthetic peptide, we generated a His-tagged full length protein in E. coli and isolated it by $\mathrm{Ni}^{2+}$ agarose affinity purification. The recombinant protein stimulated ductal cell proliferation to the same level as the INGAP peptide, but was more potent (Fig. 9 B), requiring $\sim 55$ times less protein on a molar basis.

Identification of INGAP protein in ilotropin. Since, in our previous studies, we showed that the pancreatic extract, Ilotropin, can induce islet neogenesis and reverse STZ-induced dia-

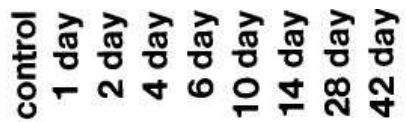

A

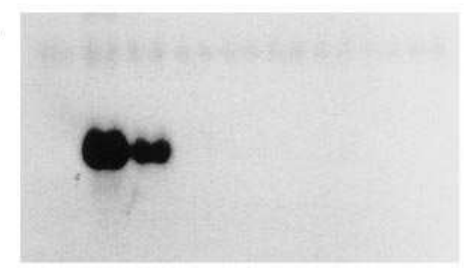

B

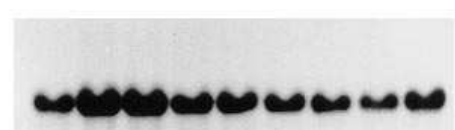

C

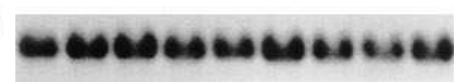

Figure 5. Northern blot analysis of INGAP and amylase gene expression in pancreatic tissue from control and cellophane-wrapped hamster pancreas. Total RNA was separated by electrophoresis and transferred to nylon membrane. Membranes were hybridized with INGAP cDNA $(A)$, amylase cDNA $(B)$, and with an 18 s ribosomal 24mer synthetic oligonucleotide probe $(C)$.

betes in the hamster, we wanted to test whether INGAP is an active molecule in the Ilotropin complex. Immunodetection on Western blots was performed using a polyclonal antibody that was raised in rabbit against a synthetic pentadecapeptide corresponding to amino acids $104-118$ of the deduced INGAP protein. The results revealed two bands in Ilotropin with an apparent mol wt of $17 \mathrm{kD}$ and $\sim 55 \mathrm{kD}$ (Fig. $10 \mathrm{~A}$ ). The membrane was stripped with $200 \mathrm{mM}$ glycine, $\mathrm{pH} 2.5$, and exposed to the same antibody blocked with excess INGAP peptide. The antibody recognition was blocked by the addition of INGAP peptide to the antibody solution prior to exposure to the membrane (Fig. $10 \mathrm{~B}$ ). The antibody recognition of a band detected in the control extract was not blocked suggesting that the nature of that band was nonspecific.

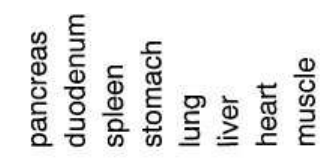

A

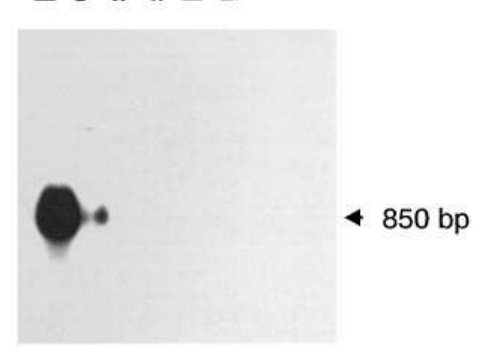

B

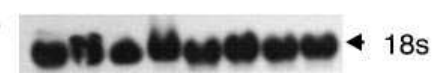

Figure 6. Northern blot analysis of INGAP gene expression in various tissues from 2 d cellophane-wrapped hamster pancreas. Total RNA was separated by and transferred to nylon membrane. Membrane was hybridized with a hamster INGAP cDNA probe $(A)$, and with an 18 s ribosomal 24 mer synthetic oligonucleotide probe to control for RNA integrity and loading $(B)$. 

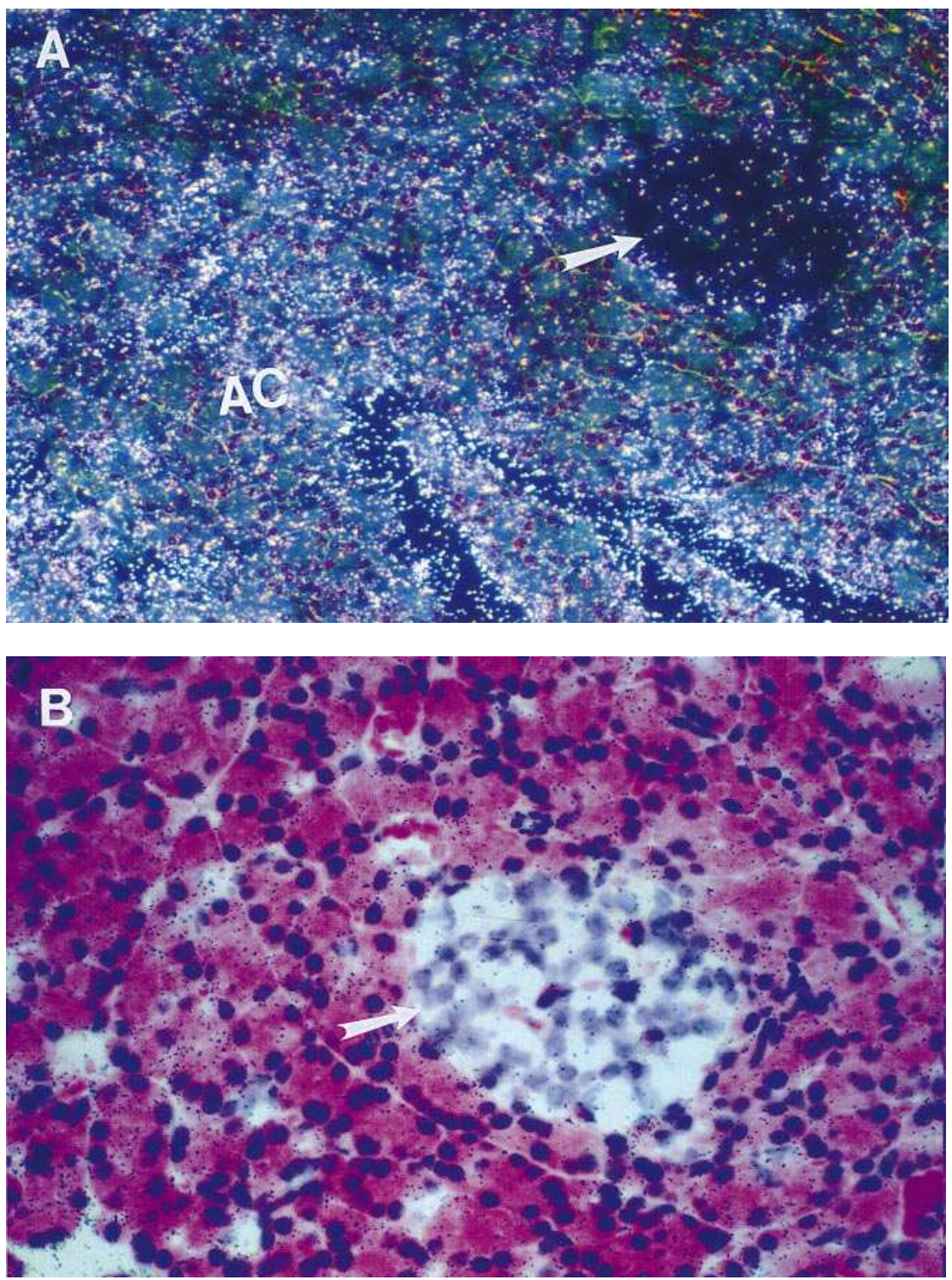

Figure 7. Localization of INGAP mRNA by in situ hybridization in control and $1 \mathrm{~d}$ wrapped pancreas. Cryostat sections from $1 \mathrm{~d}$ wrapped pancreas $(A$ and $B)$ and control pancreas $(C$ and $D$ ) were hybridized with ${ }^{35}$ S-labeled antisense single stranded INGAP RNA probe transcribed from a 766 bp hamster cDNA. ( $A$ and $B$ ) Darkand bright-field micrographs of wrapped pancreas, showing acinar cells (AC) expressing high levels of INGAP mRNA and an islet (arrow) which shows no expression of INGAP mRNA. (B) A higher magnification $(300 \times)$ of the micrograph shown in $A$ (magnification $125 \times$ ). ( $C$ and $D)$ Dark- and bright-field micrographs of pancreatic acinar cells $(A C)$ and islet (arrow) showing no expression of INGAP mRNA in control nonwrapped pancreas.

\section{Discussion}

$\mathrm{CW}$ of the pancreas induces the formation of new islets (neogenesis) from pancreatic ductal cells $(1,10)$. This occurs in the absence of an inflammatory response (1) in contrast to other models where new islets derive from existing islets and inflammation is an accompaniment $(31,32)$. A partially purified extract from $\mathrm{CW}$ pancreata, Ilotropin, when administered to hamsters rendered diabetic with STZ, lead to the induction of new islet formation with restoration of normoglycemia (11). In these studies we show that Ilotropin induces the formation of endocrine cells culminating in mature islets. The question raised is whether genes expressed in $\mathrm{CW}$ pancreata code for proteins active in Ilotropin. Using a technique to compare genes differentially expressed in CW versus control pancreata allowed us to identify a cDNA clone (RD19-2) which is uniquely expressed in CW pancreata (14). Using this cDNA as a probe we were able to isolate and sequence a novel gene, INGAP, from regenerating hamster pancreata. Reverse transcription of human pancreatic RNA followed by PCR led to isolation of the highly homologous gene from normal human pancreas. Moreover we demonstrate that a synthetic pentadecapeptide contained within INGAP sequence stimulates $\left[{ }^{3} \mathrm{H}\right] \mathrm{TdR}$ incorporation in duct epithelium and an epithelial cell line (ARIP), but has no effect on normal islets or a pancreatic islet tumor cell line (HIT-T15). This suggests that its target is within the duct cell population and not mature islets. The full length recombinant protein generated in a prokaryotic system appears to have an even more potent proliferative effect on ductal cells than the synthetic peptide.

Expression of INGAP mRNA is associated only with pancreatic islet neogenesis since it is present only after $\mathrm{CW}$ and not in control non regenerating pancreas. The time course of expression of INGAP and the site of expression is compatible with its origin from acinar tissue. Its action upon ductal cells is likely to be paracrine (11). We therefore predict that INGAP has a role in islet neogenesis. Although INGAP shows homology to the PAP and Reg/PSP families of genes (18-26), the increased expression of INGAP in CW is unlikely to be a result of acute pancreatitis. During the acute phase of pancreatitis when PAP gene expression is increased, the concentrations of most mRNAs encoding pancreatic enzymes, including amy- 


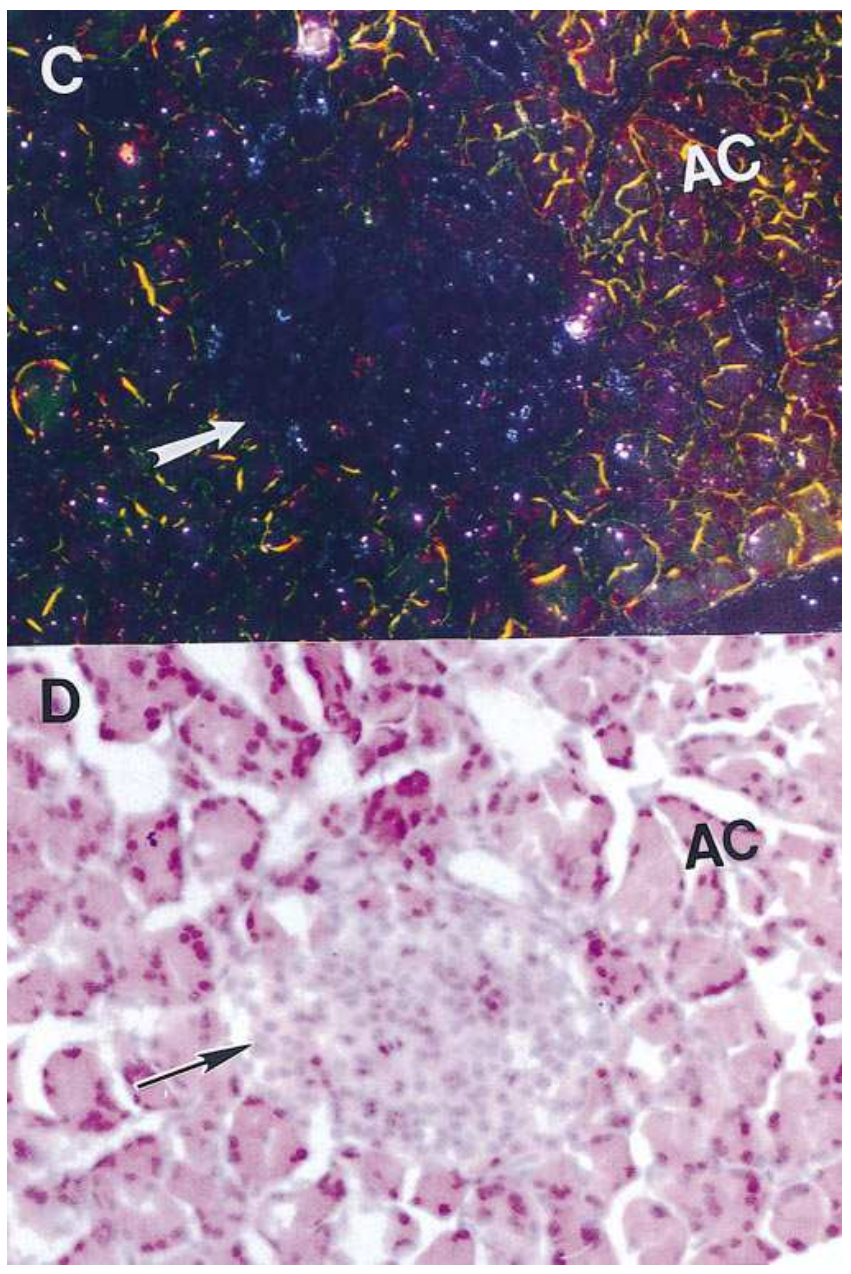

Figure 7 (Continued)

lase, are decreased significantly (33). In contrast, in the CW model of islet neogenesis in which increased expression of INGAP was found, amylase gene expression was simultaneously increased above normal rather than decreased (Fig. 5), suggesting that INGAP expression is not associated with pancreatitis but rather with islet neogenesis. Furthermore, histological sections of $\mathrm{CW}$ pancreata rarely demonstrate inflammatory changes. It seems therefore, that the functional role of the structurally similar genes and their peptide products may be quite different.

Since INGAP is expressed early after the surgical procedure and precedes duct-cell proliferation, the question arises as to whether it is necessary and/or sufficient to stimulate islet neogenesis as has been shown for the crude extract Ilotropin (11). It is possible that INGAP acts at one of the check points of cell-cycle progression at the G1/S boundary. Commitment to a cell cycle occurs as cells transit the G1 "restriction point" (34). Once beyond the check point, cells no longer require growth factors to enter the $\mathrm{S}$ phase (35). Thus, it is feasible that INGAP initiates the cell transition, and in concert with other factors within the Ilotropin complex, will induce progression and ultimately differentiation. Of particular interest are the following questions: $(a)$ how the INGAP gene may be involved in this process; and $(b)$ can it induce new islet cells that are reg-
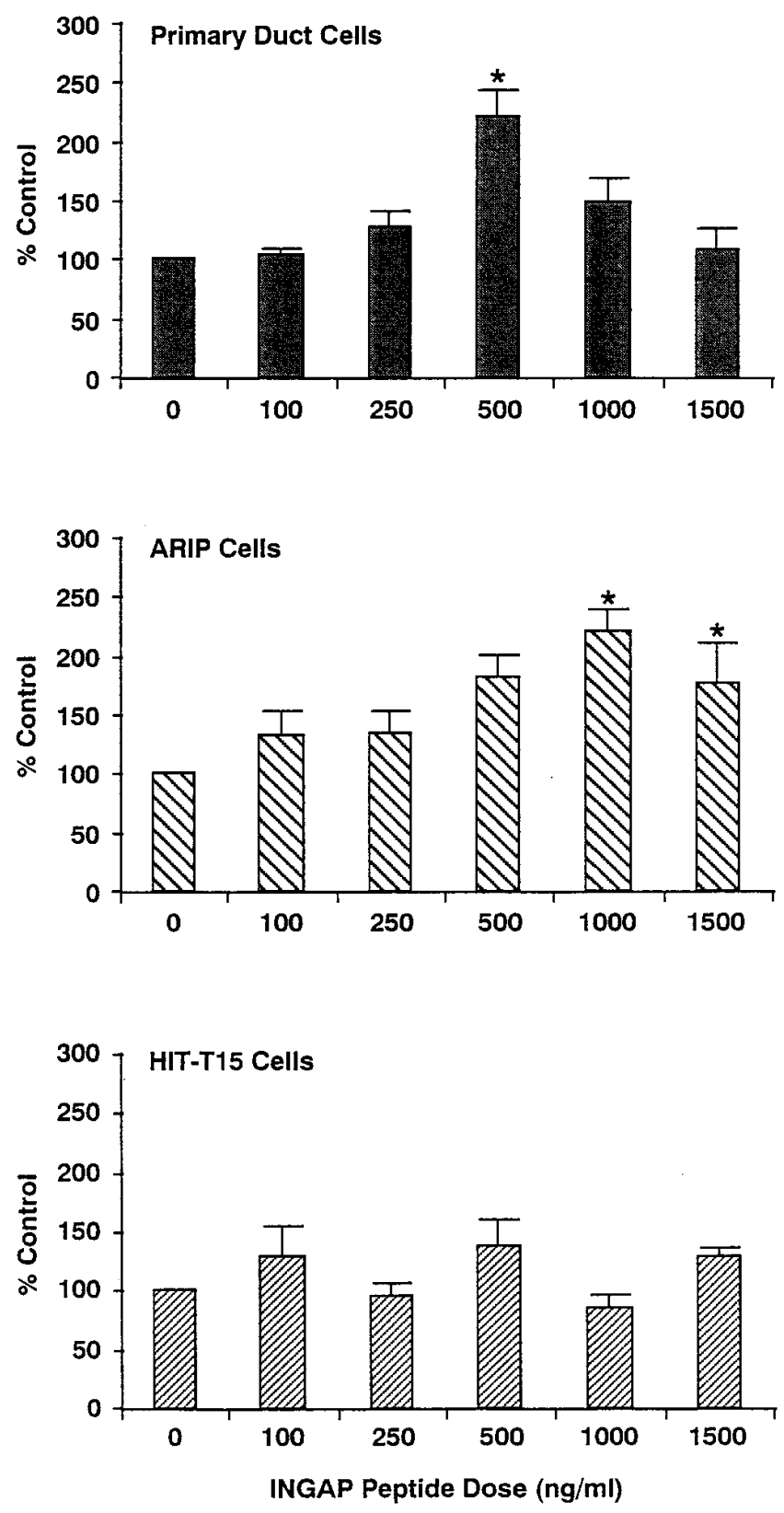

Figure $8 .{ }^{3} \mathrm{H}$-thymidine uptake by primary duct epithelial cells, ARIP and HIT-T15 cell lines treated with increasing doses of a pentadecapeptide synthetic peptide corresponding to amino acids 104-118 of INGAP. Duct, ARIP and HIT-T15 cells were treated for $24 \mathrm{~h}$ with either $100-1,500 \mathrm{ng} / \mathrm{ml}$ of peptide, or nonsupplemented media $(0 \mathrm{ng} /$ $\mathrm{ml}$ ) and then harvested. The data shown are $\mathrm{cpm} / \mu \mathrm{g}$ DNA for each treatment expressed as a percentage of control response from six experiments and expressed as mean \pm SEM $\left({ }^{*} P<0.05\right)$. Statistical analysis was performed on untransformed data.

ulated in a physiologic manner and express a milieu of genes and peptides which appear in the normal evolution of a pancreatic protodifferentiated cell into an adult islet cell as we have demonstrated for CW (2) as well as Ilotropin administration (11). Answers to these questions will provide the necessary foundation of knowledge to proceed to future studies into the induction and regulation of endocrine-cell proliferation and differentiation in other species, including humans. An im- 


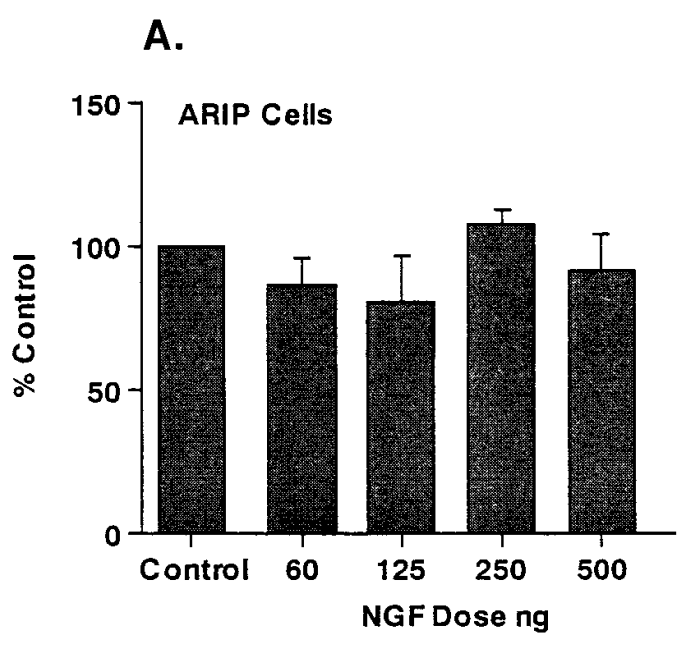

B.

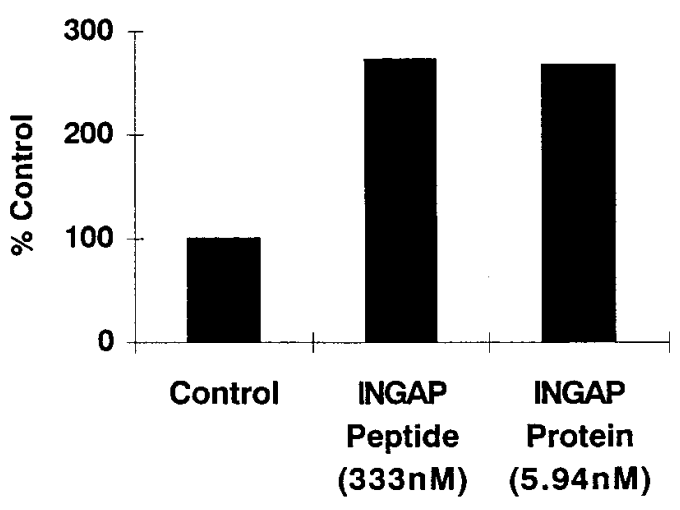

Treatment

Figure 9. ${ }^{3} \mathrm{H}$-thymidine uptake by ARIP cell line treated with NGF or full length INGAP protein. ARIP cells were treated for $24 \mathrm{~h}$ with either $60-500 \mathrm{ng} / \mathrm{ml}$ of NGF peptide or nonsupplemented media $(0 \mathrm{ng} / \mathrm{ml})$ and then harvested. The data shown are $\mathrm{cpm} / \mu \mathrm{g}$ DNA for each treatment expressed as a percentage of control response from six experiments. Statistical analysis was performed on untransformed data. NGF peptide had no significant effect $(A)$. ARIP cells were treated for $24 \mathrm{~h}$ with $5.94 \mathrm{nM}$ of INGAP recombinant protein, 333 nM of INGAP synthetic peptide or nonsupplemented media (Control) and then harvested. The data shown are $\mathrm{dpm} / \mu \mathrm{g}$ DNA for each treatment $(B)$.

portant negative finding in this study is the absence of stimulation of human islets and moderately differentiated adult tumor islet-like HIT-T15 cells. This argues against a potential role of INGAP in replication of adult islets, and supports a regenerative action upon a potential target within the ductal-acinar system. We have previously reported that regenerating pancreatic tissue contains a factor, Ilotropin, which upon administration to STZ-diabetic animals, causes islet regeneration from duct tissue and reverses the diabetes (11). We postulated the presence of a local autocrine or paracrine substance capable of initiating proliferation of a protodifferentiated cell and recapitulating fetal ontogeny to develop mature functional islets that served to ameliorate the diabetes (1). In these studies we show that Ilotropin contains a peptide encoded by a novel gene, INGAP, expressed during islet neogenesis. Furthermore, both a synthetic peptide fragment derived from the INGAP gene

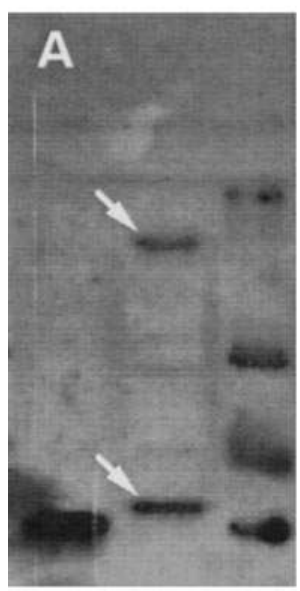

Con Ilotropin Stds

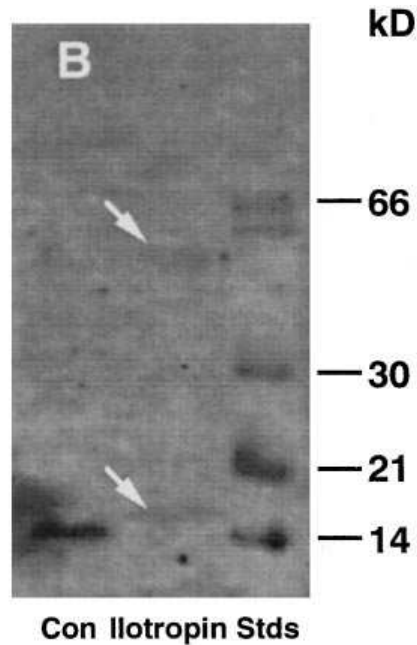

Con Ilotropin Stds
Figure 10. Western blot analysis of control extract and Ilotropin. Polyclonal antibody raised against INGAP peptide recognizes protein bands at $\sim 17 \mathrm{kD}$ and $55 \mathrm{kD}$ in the Ilotropin preparation, but not in an extract from control pancreata $(A)$. The same membrane blocked with excess INGAP peptide $(B)$ shows reduction in the intensity of both bands. Con $=$ control; Stds $=$ standard MW markers

and the full length protein appear to be able to initiate cell proliferation in pancreatic ducts and cell lines but do not do so in islets. Our evidence supports a possible role of INGAP in islet neogenesis, a prospective means of amelioration of diabetes.

\section{Acknowledgment}

This study was supported by a grant from The Diabetes Institutes Foundation, Norfolk, VA.

\section{References}

1. Vinik, A.I., G.L. Pittenger, R. Rafaeloff, L. Rosenberg, and W.P. Duguid. 1996. Determinants of pancreatic islet cell mass. Diab. Rev. 4:235-263.

2. Rosenberg, L., R. Rafaeloff, D.Class, Y. Kakugawa, G.L. Pittenger, A.I. Vinik, and W.P. Duguid. 1995. Induction of islet cell differentiation in the hamster-further support for a ductal origin. Pancreas. 13:38-46.

3. Dudek, R.W., and I.E., Lawrence, Jr. 1988. Morphologic evidence of interactions between adult ductal epithelium of pancreas and fetal foregut mesenchyme. Diabetes. 37:891-900.

4. Shaw, J.W., and E.O. Latimer. 1926. Regeneration of pancreatic tissue from the transplanted pancreatic duct in the dog. Am. J. Physiol. 76:49-53.

5. Rutter, W.J. 1980. The development of the endocrine and exocrine pancreas. In The Pancreas. P.J. Fitzgerald and A.B. Morson, editors. Williams \& Wilkins, London/Baltimore. 30-38.

6. Hellerstrom, C., I. Swenne, and A. Andersson. 1988. Islet cell replication and diabetes. P.J. Lefebvre, editor. Springer-Verlag, Berlin/Heidelberg. 141170 .

7. Kanaka-Gantenbein, C., E. Dicou, P. Czernichow, and R. Scharfmann. 1995. Presence of nerve growth factor and its receptors in an in vitro model of islet cell development: implication in normal islet morphogenesis. Endocrinology. 136:3154-3162.

8. Otonkoski, T., M.G. Beattie, S.J. Rubin, D.A. Lopez, A. Baird, and A. Hayek. 1994. Hepatocyte growth factor/scatter factor has insulinotropic activity in human fetal pancreatic cells. Diabetes. 43:947-952.

9. Bonner-Weir, S., L.A. Baxter, G.T. Schuppin and F.E. Smith. 1993. A second pathway for regeneration of adult exocrine and endocrine pancreas: a possible recapitulation of embryonic development. Diabetes. 42:1715-1720.

10. Rosenberg, L., W.P. Duguid, R.A. Brown, and A.I. Vinik. 1988. Induction of nesidioblastosis will reverse diabetes in Syrian golden hamsters. Diabetes. 37:334-341.

11. Rosenberg, L., A.I. Vinik, G.L. Pittenger, R. Rafaeloff, and W.P Duguid. 1996. Islet-cell regeneration in the diabetic hamster pancreas by restoration of normoglycaemia can be induced by a local growth factor(s). Diabetologia. 39: 256-262. 
12. Rafaeloff, R., S.W. Barlow, L. Rosenberg, and A.I. Vinik. 1995. Expression of Reg gene in the Syrian golden hamster pancreatic islet regeneration model. Diabetologia. 38:906-913.

13. Liang, P., and A.B. Pardee. 1992. Differential display of eukaryotic messenger RNA by means of the polymerase chain reaction. Science (Wash. DC). 257:967-971.

14. Rafaeloff, R., X.F. Qin, S.W. Barlow, L. Rosenberg, and A.I. Vinik. 1996. Identification of differentially expressed genes induced in pancreatic islet neogenesis. FEBS (Fed. Eur. Biochem. Soc.) Lett. 378:219-223.

15. Rosenberg, L., M. Kahlenberg, A.I. Vinik, and W.P. Duguid. 1996. Paracrine/autocrine regulation of pancreatic islet-cell proliferation and differentiation in the hamster-studies using parabiosis. Clin. Investig. Med. 19:3-12

16. Bondy, C.A. 1991. Transient IGF-I gene expression during the maturation of functionally related central projection neurons J. Neurosci. 11:34423455.

17. Pittenger, G.L., L. Rosenberg, and A.I. Vinik. 1992. The partial isolation and characterization of Ilotropin, a novel islet-specific growth factor. Adv. Exp. Med. Biol. 321:123-132.

18. Iovanna, J., B. Orelle, V. Keim, and J.C. Dagorn. 1991. mRNA sequence and expression of rat pancreatitis associated protein, a lectin-related protein overexpressed during acute experimental pancreatitis. J. Biol. Chem. 266:24664-24669.

19. Frigerio, J.M., N. Dusetti, V. Keim, J.C. Dagorn, and J. Iovanna. 1993. Identification of a second PAP. mRNA cloning, gene structure, and expression during pancreatitis. Biochemistry. 32:9236-9241.

20. Frigerio, J.M., N. Dusetti, P. Garrido, J.C. Dagorn, and J. Iovanna. 1993. The pancreatitis associated protein III (PAP III), a new member of the PAP gene family. Biochim. Biophys. Acta. 1216:329-331.

21. Lasserre, C., L. Christa, M.T. Simon, P. Vernier, and C. Brechot. 1992. A novel gene (HIP) activated in human primary liver cancer. Cancer Res. 52: 5089-5095.

22. Orelle, B., V. Keim, L. Masciotra, J.C. Dagorn, and J. Iovanna. 1992. Human pancreatitis-associated protein. J. Clin. Invest. 90:2284-2291.

23. Terazono, K., Y. Uchiyama, M. Ide, T. Watanabe, H. Yonekura, H. Yamamoto, and H. Okamoto. 1990. Expression of Reg protein in rat regenerating islets and its co-localization with insulin in beta cell secretory granules. Dia- betologia. 33:250-252.

24. Terazono, K., H. Yamamoto, S. Takasawa, K. Shiga, Y. Yonemura, Y. Tochino, and H. Okamoto. 1988. A novel gene activated in regenerating islets. J. Biol. Chem. 263:2111-2114.

25. Giorgi, D., J.P. Bernard, S. Rouquier, J. Iovanna, H. Sarles, and J.C. Dagorn. 1989. Secretory pancreatic stone protein messenger RNA: nucleotide sequence and expression in chronic calcifying pancreatitis. J. Clin. Invest. 84: $100-106$.

26. Gross, J., R.I. Carlson, A.W. Brauer, M.N. Margolies, A.L. Warshaw, and J.R. Wands. 1985. Isolation and characterization of an unusual pancreatic human secretory protein. J. Clin. Invest. 76:2115-2126.

27. Kozak, M. 1986. Point mutations define a sequence flanking the AUG initiator codon that modulates translation by eukaryotic ribosomes. Cell. 44 : 283-292.

28. Blobel, G., and B. Doberstein. 1975. Transfer of proteins across membranes. II. Reconstitution of functional rough microsomes from heterologous components. J. Cell Biol. 67:852-862.

29. Drickamer, K. 1988. Two distinct classes of carbohydrate-recognition domains in animal lectins. J. Biol. Chem. 263:9557-9560.

30. Kanaka-Gantenbein, C., A. Tazi, P. Czernichow, and R. Scharfmann. 1995. In vivo presence of the high-affinity NGF receptor TRK-A in the rat pancreas: differential localization during pancreatic development. Endocrinology. 136:761-769.

31. Gu, D., M.S. Lee, T. Krahl, and N. Sarvetnick. 1994. Transitional cells in the regenerating pancreas. Development (Camb.). 120:1873-1881.

32. Brockenbrough, J.S., G.C. Weir, and S. Bonner-Weir. 1988. Discordance of exocrine and endocrine growth after $90 \%$ pancreatectomy in rats. Diabetes. 37:232-236.

33. Iovanna, J., V. Keim, R. Michael, and J.C. Dagorn. 1991. Pancreatic gene expression is altered during acute experimental pancreatitis in the rat Am. J. Physiol. 261:G485-G489.

34. Pardee, A.B. 1989. $\mathrm{G}_{1}$ events and regulation of cell proliferation. Science (Wash. DC). 246:603-605.

35. Reed, S.I., C. Wittenberg, D.J. Lew, V. Dulic, and M. Henze. 1991. G control in yeast and animal cells. In The Cell Cycle. Cold Spring Harbor Symposia on Quantitative Biology. Cold Spring Harbor, New York. 61-67. 